Eva Harista: Penggunaan Media Pembelajaran Bahasa Indonesia untuk Anak Berkebutuhan...

\title{
PENGGUNAAN MEDIA PEMBELAJARAN BAHASA INDONESIA UNTUK ANAK BERKEBUTUHAN KHUSUS DI SEKOLAH MENENGAH PERTAMA LUAR BIASA (SMPLB) NEGERI SEPULAU BANGKA
}

\author{
Using Media in Learning Indonesian Subject for Children with Special Needs at SMPLB in \\ Bangka Regency
}

\author{
Eva Harista \\ IAIN Syaikh Abdurrahman Siddik Bangka Belitung \\ Jalan Raya Mentok Km 13, Desa Petaling, Mendo Barat, Bangka \\ Kepulauan Bangka Belitung, Indonesia \\ harista.eva@gmail.com
}

Naskah masuk: 23 Desember 2020, disetujui: 2 Juni 2021, revisi akhir: 19 Juni 2021

\begin{abstract}
Abstrak
Penggunaan media dalam pembelajaran Bahasa Indonesia antara anak yang normal dengan anak berkebutuhan khusus memiliki perbedaan. Tujuan penelitian ini adalah untuk melihat ragam media pembelajaran bahasa Indonesia yang digunakan guru di Sekolah Menengah Pertama Luar Biasa (SMPLB) Negeri se-Pulau Bangka serta kendala yang dihadapi para guru dalam proses pembelajaran bahasa Indonesia. Penelitian ini menggunakan jenis penelitian deskriptif kualitatif. Teknik pengumpulan data melalui tahapan observasi, wawancara, dan dokumentasi. Adapun analisis data dalam penelitian ini, yaitu data collection, data reduction, data display, dan conclusion drawing/verification. Hasil penelitian dapat disimpulkan bahwa media pembelajaran yang digunakan oleh guru dalam mata pelajaran bahasa Indonesia berdasarkan karakteristik ketunaan siswa berkebutuhan khusus, yaitu terdiri dari media pembelajaran audio, visual, maupun audio visual. Kendala dalam proses belajar mengajar di SLB Negeri Sungailiat, Pangkalpinang, dan Koba adalah keterbatasan sarana dan prasarana seperti ruang kelas/pembelajaran, ruang orientasi dan mobilitas, ruang bina wicara, ruang bina persepsi bunyi dan irama, keterbatasan guru, dan keterbatasan media pembelajaran.
\end{abstract}

Kata Kunci: media, pembelajaran, bahasa Indonesia, anak berkebutuhan khusus

\begin{abstract}
Using media in Indonesian language learning between normal children and children with special needs has differences. The purpose of this research is to see the variety of Indonesian language learning media used by teachers in The Extraordinary Junior High School (SMPLB) in Bangka Island as well as the obstacles faced by teachers in the indonesian language learning process. This research used descriptive qualitative approach. Data collection techniques were got through the stages of observation, interviews, and documentation. There was data analysis in this research, namely data collection, data reduction and display, conclusion and verification. From the results of the study, it can be concluded that the learning media used by teachers in Indonesian subjects are based on the disability characteristics of students with special needs; namely consisting of audio, visual, and audio-visual learning media. Constraints in the teaching and learning process at SLB Negeri Sungailiat, Pangkalpinang, and Koba are the limited facilities and infrastructure such as class / learning rooms, orientation and mobility rooms, speech building rooms, sound and rhythm perception building rooms, teacher limitations, and limited learning media.
\end{abstract}

Keywords: media, learning, Indonesian language, children with special needs 
Eva Harista: Penggunaan Media Pembelajaran Bahasa Indonesia untuk Anak Berkebutuhan...

\section{PENDAHULUAN}

Undang-undang Dasar 1945 Pasal 31 Ayat 1 dan 2 yang berbunyi, "(1) Setiap warga negara berhak mendapatkan pendidikan, (2) Setiap warga negara wajib mengikuti pendidikan dasar dan pemerintah wajib membiayainya." Dapat dikatakan bahwa pendidikan merupakan hak semua orang, termasuk bagi anak berkebutuhan khusus (ABK). Pendidikan untuk anak berkebutuhan khusus, diperkuat lagi dalam Undang-undang No. 20 Tahun 2003, tentang Sistem Pendidikan Nasional, Pasal 5 Ayat 2 dan 4 yang berbunyi, "(2) Warga negara yang mempunyai kelainan fisik, emosional, mental, intelektual, dan/atau sosial berhak memperoleh Pendidikan Khusus dan Ayat (4) Warga negara yang memiliki potensi kecerdasan dan bakat istimewa berhak memperoleh pendidikan khusus."

Pemerintah telah memfasilitasi kebutuhan pendidikan bagi anak berkebutuhan khusus dengan mendirikan sekolah luar biasa (SLB) negeri yang tersebar di seluruh penjuru Tanah Air. Selain itu, pemerintah juga memperbolehkan sekolah umum, baik negeri maupun swasta untuk menyelenggarakan pendidikan inklusi. Sekolah luar biasa maupun sekolah inklusi difungsikan untuk menaungi pendidikan ABK. Kirk dan JJ. Gallager (2000:6) menjelaskan bahwa anak berkebutuhan khusus (the exceptional child) adalah anak yang berbeda dari anak rata-rata atau normal dalam hal karakteristik mental, kemampuan sensori, kemampuan komunikasi, perilaku sosial, serta karakteristik fisik. ${ }^{1}$ Dalam mendidik dan memberikan materi pelajaran untuk anak berkebutuhan khusus juga harus menyesuaikan dengan karakteristik ABK tersebut. Adapun karakteristik siswa ABK dijelaskan dalam Peraturan Pemerintah Nomor 17 Tahun 2010 Pasal 129 Ayat 3 yang menetapkan bahwa Peserta Didik berkelainan terdiri atas peserta didik yang

a) tunanetra; b) tunarungu; c) tunawicara;

d) tunagrahita; e) tunadaksa; f) tunalaras;

g) berkesulitan belajar; h) lamban belajar; i) autis; j) memiliki gangguan motorik; k) menjadi korban penyalahgunaan narkotika, obat terlarang, dan zat adiktif lainnya; dan I) memiliki kelainan lain.

Salah satu mata pelajaran yang wajib diikuti oleh peserta didik tanpa terkecuali peserta didik ABK adalah mata pelajaran Bahasa Indonesia. Mata pelajaran Bahasa Indonesia diberikan di semua jenjang pendidikan formal, salah satunya pada tingkat sekolah menengah pertama (SMP). Pembelajaran Bahasa Indonesia dapat membantu siswa dalam pengembangan kemampuan berbahasa di lingkungannya, bukan hanya untuk berkomunikasi, tapi juga untuk menyerap berbagai nilai serta pengetahuan yang dipelajarinya (Kirk dan JJ. Gallager, 2000:5).

Ada empat standar kompetensi (SK) dalam mata pelajaran Bahasa Indonesia, yaitu mendengarkan, berbicara, membaca, dan menulis. Dalam memberikan materi tentang mendengarkan, berbicara, membaca, dan menulis untuk siswa ABK, dibutuhkan lingkungan belajar yang menunjang, baik itu tempat belajar, metode pembelajaran, strategi pembelajaran, teknik pembelajaran, pendekatan pembelajaran, sarana dan prasarana. Hal yang tak kalah penting dalam menunjang proses pembelajaran Bahasa Indonesia untuk siswa ABK adalah tersedianya media pembelajaran yang memadai sesuai dengan karakteristik ABK.

Media pembelajaran adalah alat yang digunakan oleh guru untuk membantu proses belajar mengajar yang berfungsi memperjelas makna/pesan dalam materi pembelajaran yang disampaikan, sehingga tujuan pembelajaran dapat tercapai. Selain itu, media pembelajaran juga dapat berfungsi untuk menumbuhkan motivasi belajar siswa agar tidak bosan dalam kegiatan proses belajar mengajar. Menurut Munadi, media pembelajaran dapat dipahami sebagai sesuatu yang dapat menyampaikan dan menyalurkan pesan dari sumber secara terencana sehingga tercipta lingkungan belajar yang kondusif di mana penerimaannya dapat melakukan proses 
Eva Harista: Penggunaan Media Pembelajaran Bahasa Indonesia untuk Anak Berkebutuhan...

belajar secara efisien dan efektif. (Yudhi Munadi, 2010:7)

Tentunya, penggunaan media dalam pembelajaran Bahasa Indonesia antara anak yang normal dengan anak berkebutuhan khusus sangat berbeda. Misalnya, dalam pembelajaran menulis dan memahami isi bacaan, seorang anak tunanetra harus menggunakan media pembelajaran berupa tulisan braille dan buku-buku yang menggunakan huruf braille. Dengan demikian, baik dalam teori maupun praktik, media pembelajaran Bahasa Indonesia yang digunakan oleh guru untuk memberikan materi pelajaran kepada anak tunanetra harus lebih spesifik dan mengutamakan indera pendengaran dan perabaan agar dapat mengoptimalkan kemampuan siswa ABK.

Anak berkebutuhan khusus mempunyai keunikan tersendiri dalam jenis dan karakteristiknya. Hal inilah yang membedakan mereka dari anak pada umumnya. Keragaman karakteristik anak berkebutuhan khusus terkadang menyulitkan guru dalam memberikan dan menyampaikan materi pelajaran. Untuk itu, guru harus mampu menyiapkan, menggunakan, dan mengembangkan media pembelajaran yang sedemikian rupa yang sesuai dengan karakteristik anak berkebutuhan khusus agar proses pembelajaran dapat berjalan secara optimal. Seperti yang dipaparkan oleh Mais (2016:4), perbedaan gaya belajar, minat, inteligensi, keterbatasan daya indera, cacat tubuh atau hambatan jarak geografis, jarak waktu dan lain-lain dapat dibantu diatasi dengan pemanfataan media pembelajaran.

Berdasarkan hasil wawancara guru SMPLB Sungailiat, Yunita Maiza, dijelaskan kalau dalam pelaksanaan pembelajaran pada anak berkebutuhan khusus, seorang guru harus mempunyai jiwa kesabaran yang tinggi dalam mendidik mereka. Di samping itu, seorang guru juga harus kreatif dalam membuat media pembelajaran. Media pembelajaran sangat penting bagi seorang guru di SLB untuk mengoptimalkan kemampuan sesuai dengan karakteristik ketunaan yang dimiliki oleh anak berkebutuhan khusus. Berdasarkan hasil observasi awal, beberapa guru di SLB Negeri Sungailiat terkadang berkreasi sendiri membuat media pembelajaran, seperti gambar, modul pembelajaran, dan lain-lain. Bahkan terkadang para guru membeli media pembelajaran sendiri untuk menunjang proses belajar mengajar, seperti balok huruf, poster, gambar, puzzel, dan lain-lain.

Umama, selaku guru SMPLB Sungailiat, memaparkan, walaupun dalam satu kelas ABK memiliki karakteristik ketunaan yang sama, guru tetap melakukan proses belajar mengajar dengan pola individu (one by one). Hal ini karena tingkat pemahaman dan kemampuan masing-masing peserta didik berbeda, sehingga diperlukan perlakuan yang berbeda terhadap peserta didik. Lebih lanjut, Yuliza Guru SMPLB Koba, memaparkan bahwa terkadang media pembelajaran yang sudah disiapkan oleh guru, tidak jarang menjadi sia-sia, karena dirobek, dibuang, dan dicoret oleh siswa ABK tersebut. Hal ini sudah biasa dihadapi oleh guru. Untuk itu, guru harus menyiapkan strategi dalam membuat dan menggunakan serta mengembangkan media pembelajaran sehingga dapat digunakan dengan efektif dan efisien.

Berdasarkan latar belakang di atas, penulis tertarik untuk meneliti lebih lanjut tentang ragam media pembelajaran Bahasa Indonesia yang digunakan oleh guru untuk anak berkebutuhan khusus di Sekolah Menengah Pertama Luar Biasa (SMPLB) Negeri se-Pulau Bangka, sesuai dengan karakteristik/jenis ketunaan yang dimiliki oleh siswa ABK.

\section{METODE PENELITIAN}

\subsection{Jenis Penelitian}

Penelitian ini menggunakan jenis penelitian deskriptif kualitatif. Menurut Suharsimi (2005:234), penelitian deskriptif kualitatif tidak dimaksudkan untuk menguji hipotesis tertentu, tetapi hanya menggambarkan "apa adanya" tentang suatu variabel, gejala, atau keadaan. Penelitian deskriptif adalah studi yang digunakan untuk mendeskripsikan atau menggambarkan fenomena-fenomena yang ada, baik bersifat alamiah maupun hasil rekayasa. Penelitian 
Eva Harista: Penggunaan Media Pembelajaran Bahasa Indonesia untuk Anak Berkebutuhan...

deskriptif dalam bidang pendidikan dan pengajaran adalah hal yang vital, mendeskripsikan fenomena pada berbagai jenis, jenjang, dan satuan pendidikan (Nana Syaodih Sukmadinata, 2010:74).

\subsection{Lokasi/Tempat Penelitian}

Lokasi atau tempat penelitian ini dilakukan di SLB Negeri tingkat SMP di Tiga Kabupaten/Kota yang ada di Pulau Bangka, yaitu SLB Negeri Pangkalpinang, SLB Negeri Sungailiat, dan SLB Negeri Koba.

\subsection{Sumber Data}

Sumber data dalam penelitian ini adalah sumber data primer dan sumber data sekunder. Sumber data primer sebanyak 12 orang, yaitu guru bahasa Indonesia kelas VII, VIII, dan IX dengan rincian: SLB Negeri Pangkalpinang sebanyak 4 orang guru, SLB Negeri Sungailiat berjumlah 4 orang guru, dan SLB Negeri Koba sebanyak 4 orang guru. Adapun sumber data sekunder, yaitu Kepala Sekolah SLB Negeri Sungailiat, Kepala Sekolah SLB Negeri Pangkalpinang, Kepala Sekolah SLB Negeri Koba, dan dokumen yang berkaitan dengan objek penelitian seperti Rencana Pelaksanaan Pembelajaran (RPP), benda-benda berupa media pembelajaran, buku-buku/materi pelajaran Bahasa Indonesia tingkat SMP, arsip, dan lain-lain.

\subsection{Teknik Pengumpulan Data 2.4.1 Observasi}

Observasi adalah teknik pengumpulan data yang dilakukan melalui suatu pengamatan, dengan disertai pencatatan-pencatatan terhadap keadaan atau perilaku objek sasaran (Abdurrahmat, 2006:104). Berdasarkan cara pengamatan yang dilakukan, observasi dibedakan menjadi dua bagian, yaitu observasi tak berstruktur dan observasi berstruktur (Soehartono, 2004:70). Pada penelitian ini, peneliti menggunakan observasi tak berstruktur. Peneliti langsung mengamati objek penelitian dan mencatatnya berbentuk ringkasan untuk kemudian dianalisis.

\subsubsection{Wawancara}

Teknik wawancara merupakan suatu cara mendapatkan atau memperoleh data primer yang berasal dari suatu sumber. Dalam mencari data, peneliti menggunakan teknik wawancara mendalam. Burhan Bungin mengemukakan, wawancara mendalam dimaksudkan untuk memburu "tabel hidup" yang terhampar dalam kenyataan seharihari di masyarakat. (Burhan Bungin, 2005:67). Data primer dalam penelitian ini adalah guru. Dalam penelitian ini, peneliti akan melakukan wawancara mendalam kepada guru yang mengajar mata pelajaran Bahasa Indonesia di Sekolah Luar Biasa Menengah Pertama (SMPLB) se-Pulau Bangka.

Dalam teknik wawancara ini, peneliti menyiapkan pedoman wawancara. Menurut Soehartono, pedoman wawancara (interview guide) adalah catatan garis besar tentang pokok-pokok yang akan ditanyakan (Soehartono, 2004:70). Dari pedoman tersebut, peneliti melakukan wawancara mendalam dengan mengembangkan pokokpokok pertanyaan menjadi pertanyaanpertanyaan yang sesuai dengan temuan di lapangan.

\subsubsection{Dokumentasi}

Teknik dokumentasi adalah suatu cara untuk memperoleh data dengan mengambil atau mengutip beberapa catatan, tulisan, dan gambar yang ada pada objek penelitian. Salah satunya adalah dokumentasi perangkat media pembelajaran Bahasa Indonesia yang digunakan oleh guru, arsip, RPP, dan dokumentasi proses kegiatan belajar mengajar.

\subsection{Teknik Analisis Data}

Jika dilihat dari teknik analisis data, penelitian ini menggunakan analisis data yang bersifat kualitatif. Patton menjelaskan bahwa analisis data dalam penelitian kualitatif adalah proses mengatur urutan data, mengorganisasikannya ke dalam suatu pola, kategori, dan satuan uraian. (Endang Mulyatiningsih, 2012:43). Menurut Soehadha (2008:117), tahapan dalam teknik analisis data ini adalah reduksi data, penyajian data, dan verifikasi/menarik kesimpulan. Senada dengan pendapat di atas, Miles \& Huberman mengemukakan model interaktif kegiatan analisis data kualitatif, yaitu data collection, data 
Eva Harista: Penggunaan Media Pembelajaran Bahasa Indonesia untuk Anak Berkebutuhan...

reduction, data display, dan conclusion drawing/verification

Mulyatiningsih, 2012:45--46).
3. HASIL DAN PEMBAHASAN

3.1 Deskripsi Anak Berkebutuhan Khusus

a. SMPLB Negeri Koba

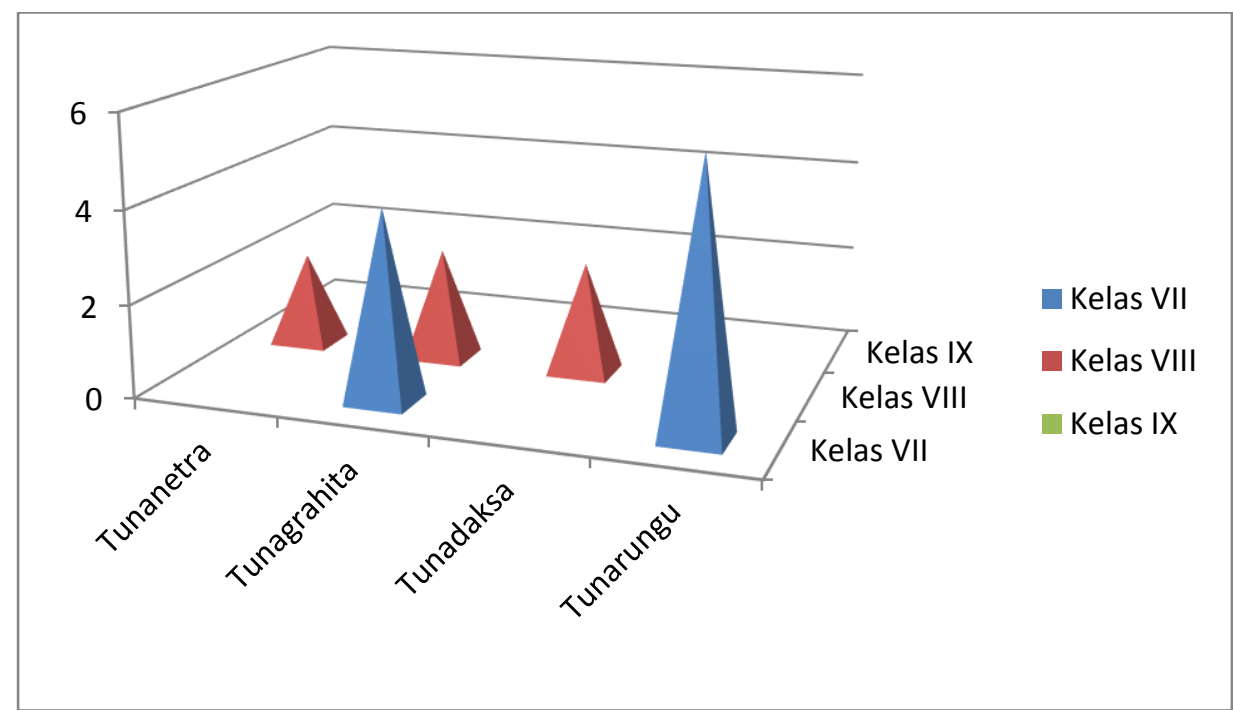

Grafik 1

Jumlah Anak Berkebutuhan Khusus Berdasarkan Karakteristik Ketunaan pada Tingkat SMP di SLB Negeri Koba

Berdasarkan grafik di atas, siswa berkebutuhan khusus tingkat SMP yang terdapat di SLB Negeri Koba berjumlah 9 siswa. Adapun rinciannya, di kelas VII terdiri dari siswa tunagrahita yang berjumlah 2 orang dan siswa tunarungu yang berjumlah 4 orang, sedangkan di Kelas VIII terdiri dari siswa tunanetra yang berjumlah 1 orang, siswa tunagrahita yang berjumlah 1 orang, dan siswa tunadaksa yang juga berjumlah 1 orang.

b. SMPLB Negeri Sungailiat

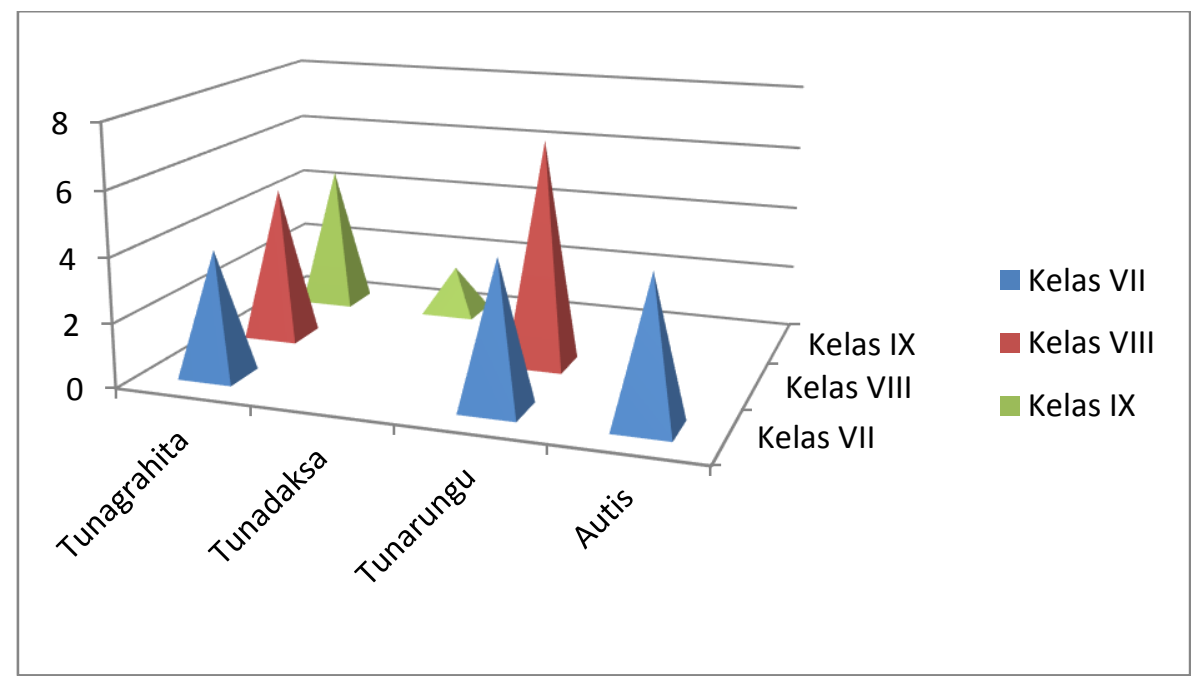

Grafik 2

Jumlah Anak Berkebutuhan Khusus Berdasarkan Karakteristik Ketunaan pada Tingkat SMP di SLB Negeri Sungailiat 
Eva Harista: Penggunaan Media Pembelajaran Bahasa Indonesia untuk Anak Berkebutuhan...

Berdasarkan grafik di atas, siswa berkebutuhan khusus tingkat SMP yang terdapat di SLB Negeri Sungailiat berjumlah 22 siswa. Adapun rinciannya adalah kelas VII terdiri dari siswa tunagrahita yang berjumlah 3 orang, siswa tunarungu yang berjumlah 2 orang, dan siswa autis sebanyak 2 orang. Kelas VIII terdiri dari siswa tunagrahita yang berjumlah 4 orang dan siswa tunarungu sebanyak 6 orang. Kelas IX terdiri dari siswa tunagrahita sebanyak 4 orang dan siswa tunadaksa berjumlah 1 orang.

\section{c. SMPLB Negeri Pangkalpinang}

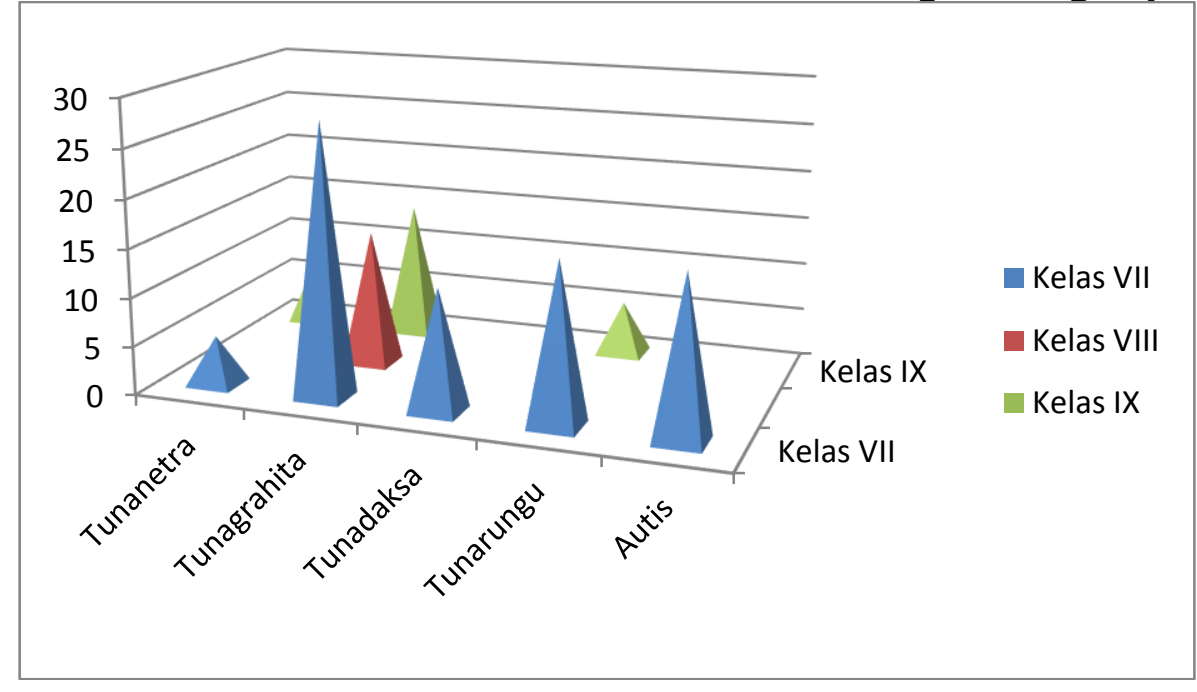

Grafik 3

Jumlah Anak Berkebutuhan Khusus Berdasarkan Karakteristik Ketunaan pada Tingkat SMP di SLB Negeri Pangkalpinang

Berdasarkan grafik di atas, siswa berkebutuhan khusus tingkat SMP yang terdapat di SLB Negeri Pangkalpinang berjumlah 64 siswa. Adapun rinciannya sebagai berikut: kelas VII terdiri dari siswa tunanetra yang berjumlah 1 orang, siswa tunagrahita sebanyak 21 orang (dengan rincian 12 orang siswa dengan tunagrahita ringan dan 9 orang siswa dengan tunagrahita sedang), siswa tunadaksa berjumlah 3 orang, siswa tunarungu berjumlah 8 orang, dan siswa autis berjumlah 7 orang. Kelas VIII hanya terdiri dari siswa tunagrahita sebanyak 9 orang (dengan rincian 4 orang siswa dengan tunagrahita ringan dan 5 orang siswa dengan tunagrahita sedang). Kelas IX terdiri dari siswa tunanetra sebanyak 1 orang, siswa tunagrahita sebanyak 11 orang (dengan rincian 5 orang siswa dengan tunagrahita ringan dan 6 orang siswa dengan tunagrahita sedang), dan siswa tunarungu sebanyak 3 orang.
3.2 Media Pembelajaran Bahasa Indonesia Anak Berkebutuhan Khusus di Sekolah Menengah Pertama Luar Biasa (SMPLB) Negeri Se-Pulau Bangka

Berdasarkan deskripsi data hasil penelitian pada tingkat SMP di SLB Negeri Sungailiat, SLB Negeri Pangkalpinang, dan SLB Negeri Koba terdapat lima karakteristik ketunaan yaitu tunanetra, tunagrahita, tunadaksa, tunarungu, dan autis.

\section{a. Tunanetra}

Tunanetra adalah seseorang yang mempunyai hambatan dan keterbatasan dalam indera penglihatan. Dengan keterbatasan ini, proses pembelajaran bagi seorang siswa tunanetra tentu sangat berbeda dengan siswa normal maupuan siswa berkebutuhan khusus yang lain. Dengan demikian, perlu adanya penunjang untuk memudahkan dalam proses 
Eva Harista: Penggunaan Media Pembelajaran Bahasa Indonesia untuk Anak Berkebutuhan...

pembelajaran. Salah satunya melalui media pembelajaran.

Media pembelajaran siswa tunanetra mempunyai ciri khas tersendiri. Media tersebut sudah didesain sedemikian rupa sehingga mampu mengoptimalkan beberapa indera yang bisa digunakan, selain dari indera penglihatan. Seperti media pembelajaran yang digunakan oleh guru di SLB Negeri Pangkalpinang, Fetra Salim menjelaskan:

"Dalam proses pembelajaran bahasa Indonesia terutama dalam membaca dan menulis, siswa tunanetra menggunakan alphabate bralille, reglet braille dan kertas braille."

Hal senada juga disampaikan oleh Guru SMPLB Negeri Koba, Ninuk Purwaningsih:

"Untuk keterampilan membaca dan menulis, siswa menggunakan media pembelajaran sama seperti halnya dengan siswa tunanetra pada umumnya yaitu menggunakan media reglet dan pena, kertas dan huruf braille."

Media pembelajaran berupa alfabet atau huruf braille, reglet braille, dan kertas braille merupakan media pembelajaran utama dalam mengembangkan keterampilan berbahasa terutama keterampilan membaca dan menulis untuk anak berkebutuhan khusus dengan karakteristik tunanetra. Berdasarkan sejarah, reglet merupakan alat tulis pertama (tertua) yang diciptakan khusus untuk mempermudah komunikasi bagi tunanetra. Reglet sudah didesain sedemikian rupa dengan pola yang digunakan untuk membuat titik-titik timbul menggunakan pena khusus mengacu pada huruf braille yang kemudian akan diaplikasikan di atas kertas braille. Huruf braille sendiri adalah berupa sistem tulisan sentuh yang mengoptimalkan indera peraba. Sistem tulisan braille diciptakan oleh Louis Braille yang juga seorang tunanetra.

Pada dasarnya, reglet mempunyai beberapa model berdasarkan kategori jumlah barisnya dan jumlah petak pada masing-masing baris. Reglet yang sering digunakan umumnya adalah reglet dengan empat baris dan 27 petak. Seperti yang digunakan di SMPLB Negeri Pangkalpinang dan SMPLB Negeri Koba. Kedua Sekolah ini pun masih menggunakan reglet sederhana berbahan plastik berwarna biru, meskipun banyak jenis reglet yang lain seperti reglet stainless kecil dan stainless besar serta reglet generasi baru.

Selain itu, media pembelajaran yang digunakan dalam pembelajaran bahasa Indonesia yang digunakan oleh guru di SLB Negeri Pangkalpinang adalah papan baca untuk memudahkan siswa dalam membaca, printer braille, mesin ketik braille, dan alat peraga. Lebih lanjut, Fetra Salim selaku guru SMPLB Pangkalpinang, memaparkan bahwa selain media pembelajaran tersebut di atas, dia juga menggunakan komputer dengan sofware JAWS dan audio digital.

Tidak jauh berbeda, media pembelajaran bahasa Indonesia yang digunakan oleh guru pada kelas tunanetra di SLB Negeri Koba, Ninuk Purwaningsih menjelaskan,

"Selain menggunakan reglet plastik, peserta didik juga menggunakan komputer dengan program JAWS, buku paket braille, dan mesin ketik tunanetra. Pada siswa tunanetra, untuk melatih kepekaan perabaan bisa melalui media pembelajaran yang konkret seperti biji-bijian, kain, amplas, dan lain-lain."

Media pembelajaran berupa papan baca merupakan salah satu alat peraga siswa tunanetra. Papan baca ini berfungsi sebagai alat untuk membantu siswa tunanetra dalam membaca braille pada tingkat dasar. Alat bantu ini dikhususkan untuk siswa tunanetra yang kurang menguasai bacatulis braille.

Demi menunjang kemampuan siswa tunanetra dalam menggunakan teknologi informasi untuk mengembangkan keterampilan baca-tulis, guru salah satunya menggunakan mesin tik braille dan printer braille. Penggunaan mesin tik braille ini pada dasarnya tidak mempunyai perbedaan yang signifikan dengan mesin tik yang digunakan oleh siswa normal. Perbedaan hanya terletak pada tombol-tombol yang dibuat sedemikian rupa yang berjumlah enam tombol. Tombol-tombol tersebut tentu terdapat titik-titik huruf braille. Pada mesin tik braille ini memiliki satu tombol 
Eva Harista: Penggunaan Media Pembelajaran Bahasa Indonesia untuk Anak Berkebutuhan...

spasi dan dua tombol di samping kiri dan kanan yang berfungsi untuk menggerakkan kertas. Sedangkan printer braille mempunyai fungsi yang sama dengan printer pada umumnya, yaitu digunakan untuk mencetak data dari komputer. Adapun hasil print out dari printer braille ini adalah bentuk huruf braille. Dengan adanya mesin tik braille dan printer braille ini siswa tunanetra bisa menunjukkan bahwa mereka juga bisa menguasai dan menggunakan teknologi dengan tepat guna serta dapat lebih mudah dalam mengembangkan kemampuan membaca dan menulis.

Media pembelajaran lain yang dikembangkan dan digunakan oleh guru SMP pada SLB Negeri Pangkalpinang dan SLB Negeri Koba adalah alat bantu sofware JAWS yang di instal pada komputer atau laptop. Melalui piranti lunak ini, semua tulisan dapat diubah menjadi bunyi sehingga dalam pembelajaran siswa tunanetra dapat mengoptimalkan pancaindera pendengaran. JAWS merupakan singkatan dari Job Access With Speech. JAWS merupakan sebuah peranti lunak berupa pembaca layar atau yang sering disebut screen reader. JAWS berfungsi untuk membantu tunanetra dalam mengunakan komputer.

\section{b. Tunagrahita}

Tuna Grahita merujuk pada seseorang yang mempunyai tingkat kecerdasan di bawah rata-rata atau normal pada umumnya. Di sekolah yang menjadi objek penelitian ini, yaitu SMPLB Negeri Sungailiat, SMPLB Negeri Pangkalpinang dan SMPLB Negeri Koba, ada dua klasifikasi siswa tunagrahita, yaitu tunagrahita ringan dan tunagrahita sedang.

Menurut Munzayanah anak tunagrahita ringan masih memiliki kemungkinan memperoleh pendidikan baik pada bidang membaca, menulis, maupun berhitung pada suatu tingkat tertentu di sekolah khusus serta dapat dilatih keterampilanketerampilan sederhana. Sebaliknya, anak tunagrahita sedang memilki keterbatasan yang lebih kompleks dibandingkan dengan anak tunagrahita ringan.

Mesra Yenti menjelaskan bahwa kelas VII dan VIII tunagrahita di SLB Negeri Koba merupakan siswa tunagrahita ringan. Dalam proses belajar mengajar pada mata pelajaran bahasa Indonesia, Yenti sering menggunakan contoh langsung secara konkret misalnya berupa gambar atau alat peraga. Hal ini karena siswanya hanya dapat membuat kalimat sederhana. Untuk lebih menunjang proses pembelajaran, Yenti menggunakan media pembelajaran seperti buku paket dan papan tulis. Selain itu, siswa juga menggunakan laptop dan memanfaatkan teknologi berupa internet untuk memudahkan proses pembelajaran bahasa Indonesia. Melalui teknologi tersebut, siswa lebih leluasa untuk mencari bahan atau materi yang sesuai dengan materi ajar bahasa Indonesia.

Hal senada dijelaskan oleh Yunita dan Ummu Qodarsih:

\begin{abstract}
"Untuk siswa tunagrahita mereka memanfaatkan media pembelajaran seperti puzzel, balok huruf, papan baca kayu, gambar-gambar, video, film untuk menggali ide cerita, dan lain-lain."
\end{abstract}

Media pembelajaran seperti puzzel, balok huruf, papan baca kayu, dan gambargambar secara tidak langsung dapat meningkatkan keterampilan kognitif, motorik halus, keterampilan sosial, melatih logika, melatih kesabaran, serta memperluas pengetahuan siswa.

Siswa tunagrahita sedang di SMPLB Negeri Pangkalpinang, dalam pembelajaran bahasa Indonesia menggunakan media pembelajaran yang tidak jauh berbeda dengan siswa di SMPLB Negeri Sungailiat. Siswa tunagrahita sedang hanya mampu membuat kalimat-kalimat sederhana dengan cara menuliskan kembali contoh kalimat yang sudah ada. Seperti yang disampaikan oleh wali kelas siswa tunagrahita sedang, "Siswa belum mampu menulis kalimat yang komplek, mereka hanya bisa membuat dan menyalin kalimatkalimat sederhana."

\section{c. Tunadaksa}

Tunadaksa adalah seseorang yang memiliki kekurangan dalam tubuh seperti cacat pada tubuh atau cacat pada fisik atau cacat ortopedi. Klasifikasi tunadaksa terdiri dari 
Eva Harista: Penggunaan Media Pembelajaran Bahasa Indonesia untuk Anak Berkebutuhan...

dua jenis, yaitu kelainan pada sistem otot dan kelainan pada sistem cerebral.

Siswa berkebutuhan khusus dengan karakteristik tunadaksa dengan kelainan pada sistem otot memiliki tingkat kecerdasan sama dengan siswa normal pada umumnya. Siswa tunadaksa hanya memiliki keterbatasan pada fisik. Oleh karena itu, dalam proses belajar mengajar, siswa tunadaksa membutuhkan alat bantu fisik salah satunya seperti kursi roda, dan lain-lain, tergantung kebutuhan fisik masing-masing tunadaksa. Sedangkan siswa tunadaksa dengan kelainan pada sistem cerebral (sistem saraf pusat) memiliki tingkat kecerdasan dengan rentang mulai dari tingkat idiocy sampai gifted.

Siswa tunadaksa di SLB Negeri Pangkalpinang dan SLB Negeri Koba terdiri dari siswa tunadaksa dengan kelainan otot. Media pembelajaran siswa tunadaksa di SLB Negeri Pangkalpinang dan SLB Negeri Koba yaitu buku paket, video, buku-buku perpustakaan, lab komputer, serta pemanfaat TIK. Pada umumnya, alat bantu fisik untuk siswa tunadaksa sangat beragam. Akan tetapi di SLB ini belum memiliki alat-alat tersebut.

Didit Detriadi menjelaskan bahwa:

\begin{abstract}
"Dalam proses belajar mengajar pada siswa tunadaksa tidak terlalu mendapat kendala karena kemampuan siswa tunadaksa pada dasarnya sama dengan siswa normal. Hanya saja ketika siswa ingin memanfaatkan lab komputer untuk proses pembelajaran tentunya keadaan menjadi tidak kondusif serta tidak efektif. Hal tersebut dikarenakan jarak antara kelas dengan lab komputer jauh, sehingga siswa tunadaksa memerlukan bantuan siswa atau guru untuk membawa mereka menuju ruang lab komputer."
\end{abstract}

Berbeda dengan keadaan di SLB Negeri Koba yang hanya mempunyai satu siswa tunadaksa dengan kelainan otot kaki. Tingkat kecerdasan siswa tersebut pun sama dengan siswa normal pada umumnya. Siswa tersebut mempunyai prestasi di Tingkat Nasional pada mata pelajaran Bahasa Indonesia. Seperti yang disampaikan oleh Guru Kelas, Elisa Noviani

\begin{abstract}
"Siswa tunadaksa kami memiliki prestasi yang sangat membanggakan baik di tingkat lokal maupun nasional yaitu menjadi juara baca puisi. Walaupun dengan keterbatasan fisik yang dia miliki tidak menghalanginya dalam meraih prestasi. Dia memiliki motivasi dan semangat yang tinggi untuk belajar seperti siswa normal pada umumnya."
\end{abstract}

\section{d. Tunarungu}

Tunarungu adalah seseorang yang mengalami gangguan dalam indera pendengaran, baik sebagian maupun keseluruhan sehingga berdampak pada lemahnya proses komunikasi terhadap orang lain. Pada observasi awal yang peneliti lakukan, secara fisik siswa tunarungu terlihat sama seperti halnya siswa normal pada umumnya. Perbedaan yang signifikan terlihat ketika terjadi proses berkomunikasi kepada siswa tersebut. dari proses komunikasi tersebut barulah terlihat bahwa siswa mengalami kendala gangguan pendengaran. Tidak hanya itu, siswa tunarungu di tiga sekolah yang menjadi lokasi penelitian ini juga mengalami ketunaan sekunder, yaitu tunawicara. Hanya ada beberapa siswa tunarungu yang mempunyai kemampuan bicara secara oral. Siswa tunarungu yang lain mayoritas tidak bisa berbicara secara normal.

Dengan adanya ketunaan ganda atau sekunder yang dialami, tentunya siswa tunarungu ini memiliki keterbatasan yang kompleks dalam proses belajar mengajar, terutama dalam proses membaca dan menulis. Hal ini menyebabkan siswa tunarungu sangat kurang dalam penguasaan kosakata. Seperti yang disampaikan oleh Guru Kelas Siswa Tunarungu di SLB Negeri Koba,

"Siswa tunarungu memiliki IQ normal/ratarata. Akan tetapi siswa tunarungu banyak sekali mengalami kendala dalam proses belajar mengajar. Mereka juga mempunyai tingkat pemahaman yang berbeda-beda. Hal ini dikarenakan penguasaan kosakata yang sedikit. Ketika dalam proses komunikasi juga guru terkadang harus memberikan contoh yang konkret/nyata sehingga mudah dipahami oleh siswa. Dalam membuat kalimat, siswa tunarungu cenderung menulis kalimat yang tidak 
Eva Harista: Penggunaan Media Pembelajaran Bahasa Indonesia untuk Anak Berkebutuhan...

teratur. Siswa tunarungu mempunyai tipikal tidak bisa berbahasa penuh, dengan pola kalimat yang sesuai. Hal ini disebabkan oleh perolehan informasi dan pemahaman bahasa atau kemampuan berbahasa mereka memang lebih sedikit dibandingkan dengan siswa normal pada umumnya."

Hal senada diungkapkan oleh Guru Kelas Siswa Tunarungu di SLB Negeri Sungailiat.

\begin{abstract}
"Siswa tunarungu tidak mengalami kendala dalam penguasaan teknologi, seperti penggunaan laptop, komputer, maupun pemanfaatan internet. Hanya saja siswa tunarungu mengalami kendala dalam penguasaan kosakata. Keterbatasan kosakata tersebut mempunyai dampak pada kemampuan menulis siswa yang rendah."
\end{abstract}

Dalam mengatasi kendala tersebut pada siswa tunarungu, guru harus menggunakan media pembelajaran yang dapat menunjang dan mendukung proses belajar mengajar. Seperti yang disampaikan oleh Guru SLB Negeri Sungailiat, "Media pembelajaran siswa tunarungu seperti papan tulis, buku paket tunarungu, laptop, internet, video, buku-buku bacaan di dalam kelas, alat peraga, cermin."

Nurul Ervina, Guru SLB Negeri Pangkalpinang juga menggunakan media pembelajaran yang tidak jauh berbeda, "saya menggunakan media infocus, power point, media cetak seperti koran dan majalah, buku paket tunarungu, buku cerita dan dongeng, komputer, internet, video, dan lain-lain."

Senada dengan hal tersebut, Guru SLB Negeri Koba, Erlisa Febrianti, juga menggunakan media pembelajaran seperti papan tulis, media gambar, kartu bergambar, video, internet, youtobe, komputer, laptop.

\section{e. Autis}

Yuliza, selaku wali kelas VII sekaligus guru mengatakan, dalam memberikan pelajaran terutama membaca dan menulis pada siswa autis menggunakan media pembelajaran visual, seperti papan tulis, balok huruf, balok warna, buku paket, dan lain-lain. Media pembelajaran siswa autis tidak jauh berbeda dengan siswa tunagrahita.

\subsection{KENDALA}

Sahara selaku Kepala Sekolah SLB Negeri Sungailiat menjelaskan kendala dalam proses belajar mengajar di SLB Negeri Sungailiat adalah keterbatasan sarana dan prasarana, termasuk ruang pembelajaran. Berdasarkan hasil observasi peneliti, ruang pembelajaran di SLB Negeri Sungailiat memang sangat memprihatinkan. Setiap ruang-ruang kelas dibagi menjadi beberapa bagian/kelas. Menurut sahara, hal ini karena jumlah siswa tak sebanding dengan jumlah ruang kelas yang ada. melihat kondisi ini, tentu proses belajar mengajar jadi tidak kondusif.

Hal yang sama di sampaikan Kepala Sekolah SLB Negeri Pangkalpinang, Warsih. Menurutnya, beberapa ruang kelas juga dibagi ke dalam beberapa kelas. Hal ini karena banyaknya jumlah siswa. Akan tetapi, kondisi ruang kelas di SLB Negeri Pangkalpinang ini lebih baik dibandingkan dengan kondisi ruang kelas di SLB Negeri Sungailiat. Adapun untuk di SLB Negeri Koba, jumlah siswa tidak terlalu banyak. Akan tetapi, tetap saja masih banyak keterbatasan sarana dan prasarana termasuk ruang kelas.

Selain keterbatasan ruang kelas, SLB ini juga belum memiliki ruang penunjang bagi siswa ABK. Ruang penunjang ini meliputi ruang orientasi dan mobilitas, ruang bina wicara, ruang bina persepsi bunyi dan irama. Ruang penunjang yang dimiliki oleh sekolah ini adalah ruang bina diri/kreativitas dan ruang lab komputer.

Berdasarkan observasi yang peneliti lakukan, keterbatasan guru juga menjadi salah satu kendala yang cukup signifikan. Untuk mengantisipasi kekurangan guru, seperti yang dilakukan di SLB Negeri Koba adalah menggabungkan siswa kelas VII dan kelas VIII tunagrahita dalam satu kelas. Begitupun pada siswa tunadaksa yang digabung dengan siswa autis dalam satu kelas. Elisa memaparkan "karena jumlah siswa tunadaksa hanya satu orang, maka untuk proses pembelajaran disatukan dengan siswa autis dalam kelas yang sama."

Tidak jauh berbeda dengan keadaan di SLB Negeri Sungailiat. Untuk memaksimalkan keterbatasan ruang kelas 
Eva Harista: Penggunaan Media Pembelajaran Bahasa Indonesia untuk Anak Berkebutuhan...

dan guru, kelas rendah dan kelas tinggi dengan karakteristik ketunaan yang sama disatukan dalam satu kelas. Seperti kelas VII dan kelas VIII pada siswa tunarungu. Tidak hanya itu, pada siswa tunagrahita dan siswa autis dengan tingkat kelas yang berbeda juga disatukan dalam satu kelas dengan satu orang guru kelas yang sama. Hal ini tentunya akan menyulitkan guru dalam memberikan materi pembelajaran dan menyulitkan siswa dalam menerima materi pembelajaran.

Hal yang hampir sama terjadi di SLB Negeri Pangkalpinang. Satu kelas dibagi dengan cara menggunakan pembatas menjadi dua kelas. Akan tetapi penataan siswa berdasarkan karakterstik ketunaan lebih baik dan sudah diperhatikan oleh SLB ini. Masing-masing kelas terdiri satu karakteristik ketunaan saja. Walaupun masih ada penggabungan kelas tinggi dengan kelas rendah dalam satu kelas. Seperti pada kelas VII dan IX tunanetra.

Berdasarkan pemaparan tersebut, keterbatasan ruang kelas dan guru menjadi kendala bagi SLB di Provinsi Kepulauan Bangka Belitung ini. Para Kepala Sekolah mulai menata dan mengelola dana dari Pemerintah agar dapat dipergunakan semaksimal mungkin demi membangun sarana dan prasarana yang dapat menunjang proses pembelajaran. Tentunya jika fasilitas sarana dan prasarana di sekolah memadai, proses belajar mengajar bagi siswa berkebutuhan khusus akan berjalan dengan kondusif.

Selain keterbatasan guru, sarana dan prasarana, keterbatasan media pembelajaran seperti, alat peraga, alat bantu fisik, dan lain-lain yang harusnya dapat menunjang proses pembelajaran ABK tidak dimiliki oleh SLB di Pulau Bangka ini. Hal ini seperti yang dijelaskan oleh, Elmi selaku Kepala Sekolah SLB Negeri Koba "Sekolah kami sangat terbatas sekali dalam media pembelajaran, padahal media pembelajaran sangat penting untuk menunjang proses pembelajaran."

\section{SIMPULAN}

SMPLB Negeri Koba terdiri dari siswa dengan karakteristik tunanetra, tunagrahita, tunadaksa, dan tunarungu. Sementara itu, SMPLB Negeri Sungailiat terdiri dari siswa dengan karakteristik tunagrahita, tunadaksa, tunarungu, dan autis. Adapun pada SMPLB Negeri Pangkalpinang terdiri dari siswa dengan karakteristik tunanetra, tunagrahita, tunadaksa, tunarungu, dan autis. Dari hasil penelitian dapat disimpulkan bahwa media pembelajaran yang digunakan oleh guru dalam mata pelajaran Bahasa Indonesia berdasarkan karakteristik ketunaan siswa berkebutuhan khusus, yaitu terdiri dari media pembelajaran audio, visual, maupun audio visual.

Siswa dengan karakteristik tunanetra menggunakan media pembelajaran huruf bralille, reglet braille, kertas dan pena braille, papan baca, printer braille, mesin ketik braille, alat peraga, komputer dengan sofware JAWS, audio digital, dan buku paket braille. Pada siswa dengan karakteristik tunagrahita menggunakan media pembelajaran seperti gambar, alat peraga, buku paket, papan tulis, laptop, media internet, puzzel, balok huruf, papan baca kayu, gambar-gambar, video, film untuk menggali ide cerita.

Pada siswa dengan karakteristik tunadaksa menggunakan media pembelajaran seperti alat bantu fisik, yaitu kursi roda, papan tulis, buku paket, video, buku-buku perpustakaan, lab komputer, serta pemanfaat TIK. Pada siswa dengan karakteristik tunarungu menggunakan media pembelajaran seperti laptop, komputer, internet, buku bacaan penunjang, papan tulis, buku paket tunarungu, video, alat peraga, cermin, infocus, power point, media cetak seperti koran dan majalah, buku cerita dan dongeng, papan tulis, media gambar, dan kartu bergambar. Adapun pada siswa dengan karakteristik autis menggunkan media pembelajaran seperti papan tulis, balok huruf, balok warna, buku paket Autis, kartu bergambar, dan media gambar.

Sementara itu, kendala dalam proses belajar mengajar di SLB Negeri Sungailiat, Pangkalpinang, dan Koba adalah keterbatasan sarana dan prasarana seperti ruang kelas/pembelajaran, ruang orientasi 
Eva Harista: Penggunaan Media Pembelajaran Bahasa Indonesia untuk Anak Berkebutuhan...

dan mobilitas, ruang bina wicara, ruang bina persepsi bunyi dan irama, keterbatasan guru, dan keterbatasan media pembelajaran.

\section{DAFTAR PUSTAKA}

Arikunto, Suharsimi. (2005). Manajemen Penelitian. Jakarta: PT Asdi Mahasatya.

(2013). Prosedur Penelitian: Suatu Pendekatan Praktik. Jakarta: PT. Rineka.

Abdurahmat. (2006). Metodologi Penelitian dan Teknik Pengumpulan Data. Jakarta: Rineka Cipta.

Anggraini, Rindy Lelly. (2014). "Proses Pembelajaran Inklusi untuk Anak Berkebutuhan Khusus (ABK) Kelas V SD Negeri Giwangan Yogyakarta." Skripsi, hal. 31-32, digilib.uinsuka.ac.id, (diakses Tanggal 29 September 2017)

Arsyad, Azhar. (2009). Media Pembelajaran. Jakarta: Rajawali Pers.

Batshaw \& Perret. (1986). Children With Handicapped $A$ Medical Primer. Baltimor Maryland: Paul H Brookes Publishing Co.

Bungin, Burhan. (2005). Analisis Data Penelitian Kualitatif. Jakarta: PT. Raja Grafindo Persada.

Delphie, Bandi. (2006). Pembelajaran Anak Berkebutuhan Khusus. Bandung: PT Refika Aditama.

Effendi, Mohammad. (2006). Pengantar Pdikopedagogik Anak Berkelainan. Jakarta: Bumi Aksara.

Geniofam. (2010). Mengasuh dan Menyukseskan Anak Berkebutuhan Khusus. Jogjakarta: Garailmu.
Hadis, Abdul. (2006). Pendidikan Anak Berkebutuhan Khusus Autistik. Bandung: Alfabeta.

Hallan, Daniel. (2001). Exceptional Children: Introduction to Special Education. USA: Prentice-Hall International.

Hamalik, Oemar. (1994). Media Pendidikan. (Cetakan ke-7). Bandung: PT Citra Aditya Bakti.

Humaira, Desni, "Pelaksanaan Pembelajaran Bahasa Indonesia bagi Anak Tunagrahita Ringan Kelas III di SLB Sabiluna Pariaman," dalam Jurnal E-JUPEKhu (Jurnal IImiah Pendidikan Khusus), Volume I, Nomor 3, September 2012.

Ibrahim, Abdulhalim. (1992). Almuwajjih Alfanniy Limudarrisy Ilugat A/Arabiyyah. Cairo: Daarulmaarif.

Jeffrey, dkk. (2005). Psikologi Abnormal. Jakarta: Erlangga.

Kauffman \& Hallahan. (2005). Special Education: What It Is and Why We Need It. Boston: Pearson Education. Inc.

Kementerian Pendidikan dan Kebudayaan. Data Referensi. http://referensi.data.kemdikbud.go.id $\_$(diakses tanggal 8 September 2017)

Kemp, J.E dan Dauton, D.K. (1985). Planning and Producing Instructional Media. (fifth Edition). New York: Harper \& Row Publisher.

Kirk dan JJ. Gallager. (2000). Educating Exceptional Children. USA: Houghton Miffin Company.

Mais, Asrorul. (2016). Media Pembelajaran Anak Berkebutuhan Khusus. Jember: CV Pustaka Abadi.

Miles, Matthew B \& A. Michael Huberman. (2007). Analisis Data Kualitatif. (terj. 
Eva Harista: Penggunaan Media Pembelajaran Bahasa Indonesia untuk Anak Berkebutuhan...

Tjetjep Rohenal Rohidi). Jakarta: UI Press.

Mulyatiningsih, Endang. (2012). Metode Penelitian Terapan Bidang Pendidikan. Bandung: Alfabeta.

Munadi, Yudhi. (2010). Media Pembelajaran. Jakarta: Gaung Persada (GP) Press.

Munzayanah. (2000). Kemampuan Merawat Diri. Jakarta: Depdiknas.

Peraturan Pemerintah Nomor 17 Tahun 2010, Pasal 130, tentang "Penyelenggaraan Pendidikan Khusus."

Peraturan Menteri Pendidikan Nasional (Permendiknas) Nomor 70 Tahun 2009, tentang "Pendidikan Inklusif (Pensif) bagi Peserta Didik yang memiliki kelainan dan memiliki potensi Kecerdasan dan/atau Bakat Istimewa."

Priyatna, Andri. (2010). Amazing Autism! (Memahami, Mengasuh, dan Mendidik Anak Autis). Jakarta: PT. Elex Media Komputindo.

Rahman, Muzdalifah, "Memahami Prinsip Pembelajaran Anak Berkebutuhan Khusus," dalam Jurnal Elementary. Volume 2, Nomor 1, Januari-Juni 2014.

Rohani, Ahmad. (1997). Media Instruksional Edukatif. Jakarta: PT Rineka Cipta.

Sadiman, Arief, dkk. (2010). Media Pendidikan: Pengertian, Pengembangan, dan Manfaatnya. Jakarta: Rajawali Press.

Sanaky, Hujair. (2009). Media Pembelajaran. Yogyakarta: Safiria Insani Press.

Sanjaya, Wina. (2006). Strategi Pembelajaran Berorientasi Standar
Proses Pendidikan. Jakarta: Prenada Media Group.

Soehadha, Moh. (2008). Metodologi Penelitian Sosiologi Agama (Kualitatif). Yogyakarta: Teras.

Soehartono, Irawan. (2004). Metode Penelitian Sosial. Bandung: PT Remaja Rosdakarya.

Soemantri, Sutjihati. (2007). Psikologi Anak Luar Biasa. Bandung: Rafika Adittama.

Soetopo, Sungkowo dan Yulie Sudartati. (2011). Bekal Menjadi Guru Profesional. Palembang: SIMETRI.

Sudjana, Nana dan Ahmad Riva. (2009). Media Pembelajaran. Bandung: Sinar Baru Algensindo.

Sukardi. (2003). Metodologi Penelitian Pendidikan: Kompetensi dan Praktiknya. Jakarta: PT Bumi Aksara.

Sukmadinata, Nana Syaodih. (2010). Metode Penelitian Pendidikan. Bandung: PT Remaja Rosdakarya.

Sulpiandia. (2017). Tunawicara: Penyebab dan Penanganannya. https://www.scribd.com/document/2 40340947/TUNAWICARA (diakses Tanggal 29 September 2017)

Sunu, Christoper. (2012). Unclocking Autism. Yogyakarta : Lintangterbit.

Wassid, Iskandar dan Dadang Sunendar. (2011). Strategi Pembelajaran Bahasa. Bandung: Remaja Rosdakarya.

Widajati, Wiwik, dkk., "Penggunaan Media Visual dalam Pembelajaran Anak Autis," dalam Jurnal Pendidikan Luar Biasa, April 2013, Volume 9, Nomor 1.

Wiyani, Novan Ardy. (2014). Buku Ajar Penanganan Anak Usia Dini 
Eva Harista: Penggunaan Media Pembelajaran Bahasa Indonesia untuk Anak Berkebutuhan...

Berkebutuhan Khusus. Yogyakarta:

Ar-Ruzz Media.

Yunus, Mahmud. (1992). Attarbiyyah wattalliim. Padang Panjang: Matbaah. 